KISS BALÁZS ${ }^{1}$

INTEGRÁCIÓ ÉS POLITIKA

Dol: 10.18030/socio.hu.2015.3.84

\title{
ABSZTRAKT
}

A Durkheim, Tarde, Lefort és Rosanvallon gondolatain alapuló összefoglaló ismertet néhány megfontolást a politikai filozófia, a politikaelmélet és a politikatudomány területéről azzal kapcsolatban, mi tartja össze a társadalmakat, s mi a politika, a politikai intézmények, a politikai ideológiák és cselekvések funkciója ebben az összetartozásban. Az áttekintés egyik fő tanulsága az, hogy az integráció nagyon sok szinten és dimenzióban zajlik, vagy éppen sérülhet: ezért nagyon szélesen lehet és érdemes a társadalmi integráció kérdéskörét megközelíteni. A szöveg elsősorban a politikai integráció aktív és passzív formáira összpontosít, mivel azonban a politika és a politikán kívüli társadalmi szférák, intézmények és cselekvések elkülönítése viszonylagos, ezért szó kerül az általában vett társadalmi integráció néhány mechanizmusára is. Mindezek nyomán hét dimenzió mentén javasolja vizsgálni a (politikai) integrációt: közösségtípus, cselekvési dimenzió, ideológiai dimenzió, objektivitás és percepció, mentális, földrajzi és időbeli összetartozás.

Kulcsszavak: Émile Durkheim, Claude Lefort, politikaelmélet, politikai integráció, multikulturális állampolgárság, kommunikáció

\section{INTEGRATION AND POLITICS}

\section{ABSTRACT}

The paper, based mainly on the thoughts of Durkheim, Tarde, Lefort and Rosanvallon, puts forward considerations from political philosophy, political theory, and political science on the old question of sociology: what keeps society together, what roles politics, political institutions, political ideologies and actions play in the integration. The main lesson drawn is that integration is to be approached in a much broader sense than national or state wide cohesion: integration should be researched on different levels above and below the nation. The paper focuses on the active and passive forms of political integration but some claims are also outlined on the mechanisms of social integration in general. Seven dimensions of integration seem relevant for research: community type, activities, ideology, objectivity versus perception, mental (cognitive and emotional), space, and time.

Keywords: Émile Durkheim, Claude Lefort, political theory, political integration, multicultural citizenship, communication 
KISS BALÁZS

INTEGRÁCIÓ ÉS POLITIKA

Az alábbiakban a politikának a társadalmi integrációban játszott szerepéről lesz szó. ${ }^{2}$ Ennek folytán a továbbiakban először az integráció általános elmélettörténeti kérdéseiről írok, majd a szöveg kifejezetten a politikai integrációs folyamatokra összpontosít. A fejezet végső célja az empirikus vizsgálódásokban felhasználható kérdések megfogalmazásával segíteni a kutatást. Ezért a továbbiakban a problémák olyan bemutatására törekszem, hogy azok viszonylag könnyen átfordíthatók legyenek empirikus kérdésekké. Lesz, ahol ez az átfordíthatóság egyszerűbb, és lesz, ahol további végiggondolásokat igényel. Természetesen a felvetett szempontoknak csak kisebb részénél adhatok közelebbi kutatási és módszerbeli ötleteket - de a felvetéseknek lehet megtermékenyítő hatásuk.

\section{ADALÉKOK DURKHEIMHEZ}

A társadalmi integráció mechanizmusainak a felmutatásával valójában arra a rövid kérdésre keressük a választ, hogy mi tartja össze a társadalmat. Ezt a kérdést pedig a szociológiában alighanem Émile Durkheim tette fel először, és adott rá klasszikus válaszokat. Fontosnak tűnik szemügyre venni azokat a körülményeket, amelyek között felveti és meg is válaszolja a bennünket leginkább foglalkoztató kérdést, mivel azok Durkheim számára nyilvánvalóan lehetetlenné tettek bizonyos válaszokat az integráció kérdésére. Érdemes tehát mintegy röviden rekontextualizálni a kérdést, nehogy természetesnek tekintsük a durkheimi válaszokat és az ő nyomvonalán haladó későbbi megközelítéseket.

\section{A durkheimi kontextus}

Durkheim 1858-ban született a lotaringiai Épinalban, alig 12 éves, amikor a Franciaország által elvesztett 1870-1871-es francia-porosz háború nyomán Lotaringia jelentős részét Elzásszal együtt Németországhoz, a formálódó Német Birodalomhoz csatolják. Rögtön adódik tehát egy tényező, mely feltétetheti a kérdést, vajon mi is tart össze egy társadalmat, például mi tarthatta össze Elzászt és Lotaringiát Franciaországgal, illetve mostantól ezek szerint Németországgal. Mindenesetre könnyű arra jutni, hogy a területi összetartozás, az egyén területhez kötődése csak viszonylagos fontossággal bír (Durkheim 1880/1990: 51).

Durkheim zsidó származású, apja rabbi, aki őt is rabbinak szánja. A család gyökerei valahová Közép-Kelet-Európába nyúlnak vissza. Megint csak: tulajdonképpen mi integrál egy zsidót egy többségében katolikus társadalomba? Különösen élesen vetődik fel a kérdés 1894-től kezdve. Ekkor kezdődik a jól ismert Dreyfus-ügy, vagyis Alfred Dreyfus-nek, egy Durkheimmel gyakorlatilag egyidős, elzászi, tehát ekkor éppen Németországhoz tartozó területről származó, szintén zsidó franciának a meghurcoltatása. ${ }^{3}$

2 A tanulmány elkészítését az OTKA 108836 sz. Integráció és dezintegráció a magyar társadalomban c. kutatás támogatta. 
Ilyenformán nem meglepő, hogy Durkheim nem a területben, nem a származásban és nem is a vallásban találja meg az integráció fő tényezőjét, hanem - mint ez köztudott - a morálban, az erkölcsökben.

Azért érdemes erre felfigyelnünk, mert napjainkban a genderen, a szexuális orientáción és más életforma pluralitási tényezőn túl éppen a vallás, a származás és a terület ${ }^{4}$ lett a legkényesebb téma. Durkheim ebben a tekintetben kettős szerepet játszhat. Egyfelől elismeri, de veszélyesnek és ellensúlyozandónak tartja az államinál alacsonyabb szintű közösségi hovatartozásokat, és csak abban a tekintetben lát bennük össztársadalmi integrációs potenciált, hogy erkölcsi nevelést nyújthatnak, s így lefokozza az ilyen közösségek egyéni fontosságát. Másfelől a mai megközelítések sem tudnak lemondani arról, hogy a szubnemzeti integráció nem mehet az országos szintúvel valójában azonosnak értett társadalmi integráció rovására, nem fenyegetheti a társadalmat széteséssel.

Durkheim francia, ekként ugyanaz a súlyos tapasztalat foglalkoztatja, mint a kor, a XIX. század harmadik harmadának a francia és más nyugati gondolkodóit: mit lehet kezdeni a tömeggel. A tömeg először a francia forradalom idején tűnik fel történelemalakító szerepben. A forradalomnak kezdetben nincsenek megnevezhető vezetői, Durkheim idejéből visszatekintve úgy tűnik, hogy a párizsi tömeg spontán módon egyszer csak megjelenik a város utcáin, a történelem színpadán, és egyre vadabb tettekre ragadtatja magát. Ráadásul a XIX. századot végigkísérik a tömeglázadások: elég, ha az 1830-as és az 1848-as francia (és európai) forradalmakat említjük, s mindezek betetőzéseképpen az 1871-es párizsi kommünt, amelyik megint azt mutatja, hogy a társadalom testében, tereiben megjelent sok-sok ember, akik fellázadnak a társadalom rendje ellen, akik tehát nem integrálódtak a társadalomba.

Se szeri, se száma a tömeggel, a tömeg kezelésével kapcsolatos korabeli munkáknak. Hyppolite Taine (1878) sokat ír a tömegnek a nagy forradalomban játszott szerepéról. Az olasz kriminológiai iskola, például Césare Lombroso (1876), Enrico Ferri (1881) és Scipio Sighele (1895) a bűnöző tömeggel foglalkozik, s Gabriel Tarde, Durkheim nagy ellenfele is összehasonlító kriminológiai múvel kezdi a pályáját (1890). 1895-ben pedig megjelenik Gustave Le Bon (1895/2012) nagyhatású múve a tömegek lélektanáról, melyet Freud (1921/1995) még évtizedekkel később is nagy egyetértéssel idéz és kommentál. A tömeg sokszor artikulálatlannak minősülő lázadásai felvetik az integráció hiányának és sérülésének a kérdését, márpedig a francia gondolkodás, fóleg a pszichológia, melyből a szociológia éppen kilábalni szeretne, általában a sérülések alapján teszi fel kérdéseit. Mi integrálhatná ezeket a tömegeket? S mit is jelentene az integráltságuk?

\section{Durkheim és Tarde}

A szociológia későbbi sorsára és az integráció kérdésének a megítélésére nem kis hatása volt a Durkheim és Tarde között lefolyt századfordulós vitának. A korban idősebb Tarde az egyetemi életet leszámítva minden jelentős szociológiai pozíciót megszerzett, mire Durkheim a színre lép, az utóbbi tehát az egyetemi oktatásban tör az élre, éspedig teljes sikerrel. Akkoriban egyáltalán nem lehetett világos, hogy a Tarde-Durkheim versenyben ki fog győzni, már csak azért sem, mert a két szociológus a francia társadalomtudományi és kulturális élet

4 Felértékelődött a lokális terekhez kötődés identitás munkában játszott szerepe. Lásd ehhez például Frampton 1985 és LefaivreTzonis 2003. 
egy-egy táborát tudhatja maga mögött (Clark 1969). Durkheimet az úgynevezett karteziánusok támogatják. Ez a tábor a társadalom felülről történő átalakításának a híve, egyfajta társadalommérnökség jegyében gondolkodik. Tarde pedig az úgynevezett spontaneistákhoz tartozik, akik inkább alulról építkeznének, s nevük is mutatja: szerepet szánnak a nem determinált, spontán egyéni kezdeményezéseknek. A két tábor rendelkezik politikai ambíciókkal: másképp és másképp akarják átalakítani Franciaországot. Ma már tudjuk, hogy - politikai okokból - Durkheim tábora győz majd, látjuk ezt abból, hogy Tarde-ra nem sokan emlékeznek manapság, ${ }^{5}$ ezzel szemben a győztes Durkheimre támaszkodó funkcionalista szociológiai és társadalomtudományi hagyomány mindmáig nagyon erős.

A sors fintora, de az integráció megközelítésének durkheimi útját jelzi, milyen fontossá vált Durkheim az antropológiában és a mikroszociológiában (Collins 1994), holott mindkét irány tulajdonképpen ellentétes a francia klasszikus eredeti intencióival, és inkább Tarde-hoz illenék. Durkheim a népes és differenciált modern társadalmakkal foglalkozott, s a múlt csak annyiban érdekelte, amennyiben a régi, kisebb, és szerinte ezért egyben egyszerúbb társadalmakban rátaláljon a modernekben is érvényesülő funkciók és mechanizmusok jelenlétére. Unilineáris történelemfelfogása éppenséggel arra ösztönözhette volna az antropológusokat, hogy utasítsák el a durkheimi megközelítést mint olyat, amely nem képes megvilágítani a kisméretű és régi közösségek specifikumait. Úgy túnik azonban, hogy ennek az ellenkezője történt: az európai, és ezen belül durkheimiánus gondolkodásmód jegyében az antropológusok nemzedékeinek sora társadalomnak tekintette vizsgálatának tárgyát, vagyis valami olyannak, amilyenek a modern társadalmak, hasonló funkciók érvényesülésével, csak egyszerúbb formában.

Különösen érdekes a mikroszociológia útja. Mint láttuk, Durkheim és Tarde vitája alapvetően azon alapult, hogy Durkheim makroszinten gondolkodott a társadalom múködéséről, Tarde pedig az egyénből indult ki. A vita, föként a híveik vitája, ádáz volt, egyik fél sem engedhetett, így Tarde-nak mintegy meg kellett halnia ahhoz, hogy Durkheim megírhassa azt a munkáját, a Vallási élet elemi formáit, amelyik a leginkább reflektál a kisméretű közösségekre, s a társadalmi integrációt illetően a fizikailag is együtt levő, egymásra a fizikai érintkezés révén is hatni tudó embercsoportra. Erre a face-to-face szituációra, egyáltalán, a nagy intézményesített funkciók helyett a konkrét szituációkra épülő társadalomvizsgálat vált az egyik izgalmas megközelítés móddá: Erving Goffman (1961) jól, Thomas Scheff (1990) kevésbé ismert képviselője az irányzatnak.

A szintén az ehhez a durkheimi hagyományhoz tartozó Randall Collins szerint a társadalmat interakciós rituálék láncolataként is fel lehetne fogni - ha tehát azt kérdezzük, mi integrál egy embercsoportot, akkor az egyik válasz az lehet, hogy az interakcióik, főként a sikeresek (Collins 2004). A társadalom sem nem az ágens, sem nem a struktúra/intézmény elsőbbségén nyugszik, hanem olyan interakciókon, amelyekben mind az ágensek, mind a struktúrák jelen vannak, de egyik sem uralkodik. Az ágens valamilyen értékrenddel, valamilyen érdekekkel, akár alattomos stratégiával is lép bele a szituációba, az interakcióba, ám nem marad érintetlen az interakció által. Nem az történik tehát, hogy az ágens vagy tudja érvényesíteni az érdekeit, és akkor számára az interakció sikeres volt, vagy ha nem képes rá, akkor megsemmisítő vereséget szenved és alárendelődik a nagy struktúrákat érvényesítő másik félnek. Az interakcióban a résztvevőkkel olyan események történhetnek, a részt- 
vevők tudatában és érzelmeiben olyan változások mehetnek végbe, és általában végbe is mennek, amelyekre senki sem számított előzőleg. Ennek folytán közös, előzetesen senki által sem birtokolt tudás és érzelem jön létre, mely új cselekvésekre sarkallja a résztvevőket. Nincsen itt szó konszenzusról vagy boldog összeolvadásról, de számtalan rögtönzésről és a kiinduló szituáció nyomán új, nem várt szituáció kialakulásáról nagyon is.

Az interakció peremfeltételei természetesen fontosak, tudományosan le is lehet őket írni, mint ahogyan azokat a vélhető kiindulópontokat, érdekeket, érzelmeket és értékeket is, amelyekkel a partnerek belépnek a struktúrák által is befolyásolt szituációkba, illetve szándékosan létrehoznak szituációkat. Az azonban aligha jósolható meg teljes bizonyossággal, hogy hogyan alakul a szituáció az interakció folyamán, s hogy milyen új szituációhoz vezet, ezen belül a partnerek milyen új állapotához.

Az ilyen felfogás olyan irányokba tereli a társadalmi integráció kutatását, amelyek sem a funkcionalizmus, sem a racionális döntések elmélete, sem pedig a konfliktuselméleti megközelítések számára nem jelentkeztek. Fontossá válik a racionális mérlegelés mellett az érzelmi viszonyulás kérdésköre is (Kiss 2013, 2014). Lehetséges lesz annak az elfogadása, hogy autonómiát tulajdonítsunk a cselekvőknek: nem kell, sőt, nem célszerű azt feltételeznünk, hogy a cselekvő a szociológiai és egyéb strukturális beágyazottsága, determinációi okán így vagy úgy fog cselekedni. Belátjuk majd, hogy a cselekvések megértése valóban a leginkább utólagos, vagyis például arra támaszkodik, ahogyan a cselekvők utólag narrativizálják és racionalizálják tetteiket, s hogy az utólag megállapított összefüggésekből nem lehet azon nyomban a jövőre utaló cselekvési szabályokat meghatározni, ahogy azt Durkheim (2001: 50-51) gondolta. Nem elegendő csupán országos és egyéni szinteket különíteni el a folyamatok és meghatározók vizsgálatában stb.

A társadalmi integráció kutatása számára az egyik legfontosabb összefüggés az lehet, hogy nem csak a nagy társadalom által szentesített formák integrálhatják a polgárokat és az ő csoportjaikat. Az egyes szituációk is integratív mechanizmusok, nemcsak a család, a munkahely, az egyházközség, a civil egyesület, a párt vagy az állam.

Lezárásképpen kanyarodjunk vissza Durkheim vitapartneréhez, Gabriel Tarde-hoz. Tarde szociológiájának és társadalom felfogásának a középpontjában tehát az egyén áll. Úgy véli, hogy a társadalmat az utánzás (imitation) és a beszélgetés (conversation) tartja össze (Tarde 1890). Valaki kitalál valamilyen új dolgot, legyen az technikai újítás, vagy új hajviselet, és ez lassan szétterjed a társadalomban, de persze úgy, hogy közben valaki más ettől függetlenül, vagy ennek hatására szintén kitalál valamit, és így a sok-sok innováció és utánzás egymásba érő, egymást felerősítő vagy kioltó vízgyűrűi adják a társadalom mozgását. A másik központi fogalma a beszélgetés (Tarde 1901), az ugyanis, hogy az egyén nem áll védtelenül és magányosan a társadalomban, hanem valamilyen kisebb-nagyobb közösségnek a tagja, amelyben megbeszéli a dolgait, a kívülről érkező impulzusokat és kezdeményezéseket.

Jól érzékelhető, hogy miközben Durkheimhez is visszaköthetünk számos modern jelenséget és teoretikus kiindulópontot, mégis mintha számos vonatkozásban Tarde ma korszerúbb lenne, mint győztes ellenfele. 


\section{POLITIKAI INTEGRÁCIÓS MECHANIZMUSOK}

Nem nehéz olyan nézőpontot találni, amelyikből végigtekintve a politikatudomány, fóként a politikaelmélet történetén és munkáin, szinte az összes a társadalom integrációjáról szól. Ha akarjuk, azt is mondhatjuk, hogy Platónt is ez érdekli, amikor az Államban attól teszi függővé az ideális politikai közösséget, hogy mindenki azt csinálja-e, amire a legalkalmasabb. Arisztotelész a Politikát azzal kezdi, hogy az ember politikai lény, vagyis természeténél fogva együttélésre, társadalomalkotásra termett. A szerződéselméletek eleve azt kérdezik, hogy mitől gondolják úgy az emberek, hogy valamely állam hatalma alatt kell vagy érdemes élniük. Nem annak a kiválogatása nehéz, mi szól a politikai integrációról, mint inkább azé, ami nem arról szól.

Az alábbiakban előbb a politikai filozófia magasából tekintek a társadalmi integráció kérdésére. Ez a kérdezési irány vagy normatív, vagy nagy történelmi és antropológiai összefüggéseket vázol. A következő szint tulajdonképpen két eltérő szempontot érvényesít. Először azokat a politikai intézményeket veszem szemügyre, amelyek szolgálják és szolgálhatják a társadalmi integrációt, majd pedig azokat a formákat, amelyeket az állampolgárok igénybe is szoktak venni. Azt gondolom ugyanis, hogy a politikai berendezkedés felkínál olyan formákat és intézményeket, amelyek önmagukban integrálnak valakit, vagy valamely állampolgári csoportot; ilyen például az állampolgárság. Más felkínált intézmények és formák pedig az állampolgár rendelkezésére állnak ahhoz, hogy a politikai közösséghez tartozónak érezhesse magát, megélhesse és performálhassa ezt az odatartozását, a politikai identitását. Másik szempontom viszont az, hogy vajon milyen módon élik meg és performálják valóságosan is az állampolgárok a politikai közösséghez tartozásukat.

Le kell szögeznem mindjárt az elején, hogy a politika lételeme a konfliktus, az ellentét. Ilyeténképpen a politika maga is hoz létre dezintegrációs folyamatokat, nem pedig pusztán visszatükröz vagy képvisel mélyben megbúvó gazdasági, szociális, identitásbeli, kulturális, vallási stb. ellentéteket. Éppen fordítva: a nyertes politikai koalíció létrehozatala érdekében maguk a politikusok, a politikai szervezetek, további politikai aktorok kínálnak fel ellentéteket a társadalom számára (Riker 1982). Kétségtelen, hogy nem mindegyikre lesz vevő, illetve nem mindegyikre lesz kellő számú vevő ahhoz, hogy a politika tőkésíthető megosztottságává váljék, de nem egy közülük visszahat arra, ahogyan és amennyire az állampolgárok megosztottnak látják a társadalmat maguk körül, illetve arra, ahogyan és amennyire integráltnak vagy dezintegráltnak látják magukat benne. A politika, a politikai szféra tehát egyáltalán nem csak a társadalmi integrációt szolgálja, hanem adott esetben dezintegrációs hatásokkal is járhat.

A konfliktusok azonban nemcsak negatívak lehetnek, hanem pozitívak is. Könnyú belátni, hogy amíg van vita, van veszekedés, addig még értékkel bír a kapcsolat, a közösség fenntartása; ebben az értelemben a vita nem dezintegrációs, hanem inkább integrációs mechanizmus (Szabó 1996). Csak azoknak nagyon sötét a kép, akik minden áron konszenzust várnak el a társadalomtól, de legalább a politikától. Ha nem azt várunk el, akkor a vitát akár pozitív dolognak is tarthatjuk. 


\section{POLITIKAI FILOZÓFIA}

\section{Ideológiai integráció}

Induljunk el újra Durkheimtől. Durkheim osztozik hazája korabeli gondolkodóinak abban a töprengésében, hogy vajon különösen azt követően mi tartja össze a társadalmat, hogy a királyt lefejezték. Mindmáig fontos kiinduló pont ez a francia gondolkodásban, egyik XX. századi megfogalmazója Claude Lefort $(1978,1981)$.

Lefort szerint a monarchiát mint társadalmi-politikai formát a fejedelem szuverén hatalma határozta meg. A király az Isten felkentje, hatalmának forrása ezért a jelenvaló világon kívül esett, transzcendens volt. A társadalom egysége, integráltsága az uralkodó kettős testében lelt megfogható reprezentációra. ${ }^{6}$ A király lefejezésével, a demokrácia megszületésével azonban a hatalom forrása kiürül; a hatalom központja üres hely, melyet nem lehet elfoglalni.7 Az új berendezkedés a politikai szereplők számára csak azt teszi lehetővé, hogy ideiglenesen gyakorolják a hatalmat, azt nem, hogy kisajátítsák. Azt gondolhatnánk, hogy a nép az, amié a szuverenitás, tehát ő a hatalom forrása, s hogy a választásokkor nyilvánítja azt ki. Ez azonban téves, ugyanis a választások alkalmával az állampolgárok statisztikai adatokká silányulnak. Nem véletlen, hogy a XIX. században gyakorlatilag minden demokratikus politikai irányzat ellenezte az általános választójogot, hiszen az a nép egysége helyett annak megosztottságát fejezné ki, illetve hozná létre (Rosanvallon 1992). Ez egyben adalék ahhoz a gondolathoz, hogy a választások milyen értelemben lehetnek a politikai integráció mechanizmusai.

Végül is hogyan nyilváníthatná ki egységesen a nép, hogy ő a hatalom forrása, ha egyszer azt látjuk, hogy a választásokon sosem vesz részt mindenki, aki a néphez tartozik? Még ma is, amikor meglehetősen széles körben van mód a választásokon való részvételre, bizonyos kor alatt vagy valamilyen cselekvőképességbeli korlátozottságra hivatkozva sokakat kizárnak a választásokból. Ráadásul a választások sosem vezetnek valamelyik politikai erő százszázalékos támogatottságához, hanem az mindig részleges, következésképpen „a számok felváltják a tartalmat".

A politikai beszédekben oly sokszor emlegetett társadalmi és nemzeti egység tehát nem alapozható sem a transzcendenciára, sem bárminek a valós meglétére, ezért a demokrácia azt követeli, hogy az egységet folyamatos diszkurzív és ideológiai munkával teremtsék meg, teremtsék rendszeresen újra, performálják és erősítsék meg. De ez az ideológiai munka nem utalhat semmilyen transzcendens forrásra, semmire, ami stabil és meghatározott. Ez pedig a demokrácia radikálisan történeti jellegéhez vezet (Rosanvallon 2006): a demokráciának nincsen valamilyen örök formája, amelyik az aranykorban jellemezte, vagy amelyik felé tart vagy tartania kellene, nincsen valamilyen lényege, amelyik jól-rosszul megjelenik koronként. A demokrácia azonos a történelmével, mert nem más, mint ami az adott történeti korban létezik. Ez egyben azzal jár, hogy a demokrácia formálódásában lényegi szerepet játszik a diszkurzív és ideológiai munka.

6 Ernst Kantorowicz (1957) óta ismerjük a király kettős testének gondolatát. A felfogás eredete Krisztusig nyúlik vissza, akinek egyszerre volt halandó teste és halhatatlan létezése is. A gondolat hétköznapi megjelenése az uralkodó halálakor rituálisan felhangzó „Meghalt a király! Éljen a király!” felkiáltás, mely egyszerre jelenti be a király biológiai testének halálát és politikai testének, s egyben a társadalomnak, mint politikai testnek a továbbélését.

7 A gondolat Jacques Lacan alapján tehető világossá, de erre itt nincsen alkalmunk. 
Lefort (1978) szerint az ideológia legfontosabb problémája mindig az, hogy mi is tartja össze a társadalmat, az emberi közösséget. Három modern ideológiát különböztet meg: a burzsoát, a totalitáriust és az úgynevezett láthatatlan ideológiát.

A burzsoá ideológia a XIX. században volt fontos. Nagy átfogó kategóriákat, fogalmakat, jelszavakat, ideologémákat dolgozott ki a társadalom egységének létrehozatala végett. Olyan fogalmakra kell gondolni, mint az Emberiség, a Haladás, a Természet, az Élet, a Köztársaság, a Tudomány, a Művészet, a Tulajdon, a Család, a Rend, a Társadalom, a Nemzet stb. (Lefort 1978: 300). Csupa olyan fogalom, amitől azt várták, és nem is siker nélkül, hogy megfogalmaz valamit abból, ami közös az emberekben, ami alapján átélhetik az összetartozásukat.

A totalitárius ideológia az egység problémáját az egyedüli párt segítségével oldotta meg (Lefort 1981). Azt állította, hogy a Párt a szuverén képviselője, ugyanis a Népből jött, azzal folyamatosan kapcsolatot tart, attól sosem szakad el, ezért gyakorolhatja a hatalmat, amelynek a forrása a Párt mögött egységesen álló nép. Ily módon az állam összeolvad a néppel, a politika azonos a társadalommal. Nem azért lesz tehát minden politikaivá, mert az állam vagy a párt túlterjeszkedik a saját terrénumán, hanem azért, mert ez a dolog természete. A totalitárius ideológia számára a részrendszerek autonómiájának nem is lehet értelme.

Lefort korunk ideológiájának középpontjába a társadalmi kommunikációt és a csoport fogalmát helyezi. A mai ideológia integráló motívuma az, hogy mindenki valamilyen csoporthoz tartozik, s hogy a társadalmat a kommunikáció tartja össze. Ha a burzsoá ideológia rá próbálta oktrojálni a maga nagy átfogó fogalmait az emberekre, s ezért nagyon is látható volt és felülről jövő, akkor a mai ideológia láthatatlan, mert csak annyit állít, hogy maga a kommunikáció integrál, függetlenül a tartalmától. A kommunikáció jó része egyet nem értés, éppen nem konszenzus, ám az ideológia szerint nem szükséges a konszenzus ahhoz, hogy a társadalom egyben maradjon, az is elegendő, ha fennáll a kommunikáció.

A lefort-i politikai filozófia alapján a társadalmi integráció politikai mechanizmusait keresve egyrészt arra kell figyelnünk, hogy milyen nagy fogalmak vannak jelen a közéleti diskurzusokban, és ezek mennyire ismertek és elfogadottak az állampolgárok számára - ez volna a társadalmi integráció burzsoá ideológiai mechanizmusa. Másrészt pedig arra, hogy a csoporthoz, a beszélgető csoporthoz tartozás mennyire van jelen a társadalomban és az egyes állampolgárok életében - ez a láthatatlan ideológia jelenléte.

\section{A multikulturális állapot}

A multikulturális társadalom paradigmája szintén politikafilozófiai szinten tárgyalja a társadalmi integráció kérdését. Will Kymlicka (1995, Kymlicka-Norman 2000) tulajdonképpen az intézményekből való kiábrándulást teszi meg kiindulópontnak - természetesen a bevándorlás kulturális sokszínűséget okozó következményei mellett.

Azt mondja, hogy mind a száz évvel ezelőtti gondolkodók, mind pedig a politikai berendezkedés fejlődése és ideológiája a racionalizálást és racionalizálódást hirdette és javasolta. Emlékszünk Durkheimre: ha felismerjük a viselkedési törvényszerűségeket, akkor azokat átfordíthatjuk kötelező szabályokká, melyeket intézmények, intézményesített közegek érvényesítenek és tartatnak be. A tömeg, a sokféle ember a maga individualitásában aligha rendeződik össze racionális egésszé, ám az intézményesedésre a racionalizálódás jellemző (lásd Webert), 
már csak azért is, mert az intézményeket a racionális és átlátható feladatmegoldás érdekében hozzák létre. Csakhogy idővel az intézmények elszaporodnak, s először csak az a tapasztalat jelenik meg, hogy mintha kioltanák egymás racionalitását, majd eluralkodik és megfogalmazódik az a tapasztalat is, hogy az egyes intézmények önmagukban sem racionálisak.

Ennek a mi számunkra két fontos következménye van. Az egyik a politikai személyiség felértékelődése, a másik pedig az egyéni esetlegességek fontosságának megnövekedése.

A politikai személyiség felértékelődését vezéresedésként is meg szokták fogalmazni (Körösényi 2005). Mivel az intézmények nem átláthatók, elszakadtak az emberi léptékektől, ezért az állampolgár már nem róluk feltételezi azt, hogy képviseli az érdekeit, vagy képviseli az egész politikai közösség érdekeit. Az intézmények helyett megint az előtérbe kerültek a politikusok, a politikai vezérek. Számos állampolgár számára a politikai közösséget a vezér testesíti meg, integrálja, vagyis maga az állampolgár is az ő személyéhez kötődve érzi magát valamely politikai közösség tagjának (Hogg 2001, Huddy 2001).

A másik következmény szintén perszonalizációs jellegű, de itt nem a politikusra, hanem az állampolgárra irányul a figyelem. Kiderült ugyanis, hogy az intézmények működése jelentős részben a bennük dolgozó és a velük kapcsolatba kerülő emberek viselkedésétől is függ. Például bármilyen jól átlátható is a választás mint a politikába beleszólás és bevonódás intézménye, apátia lett úrrá az állampolgárok mind nagyobb részén, vagyis a legitimáció talán legfontosabb intézménye nem múködőképes az állampolgár együttmúködési készsége nélkül. Hasonlóképpen: bármilyen agyafúrt intézményrendszert talál is ki az állam például a környezet megóvása érdekében, az állampolgár zöld elkötelezettsége nélkül ezek alig múködnek. ${ }^{8}$

A felismerés kezdetei tulajdonképpen a harmincas évekig nyúlnak vissza. Ekkortól kezdik a vállalatok felismerni a dolgozók közötti emberi kapcsolatok fontosságát (Illouz 2008). A történet jól ismert: a XIX. században a tömeg betörésének és ipari munkára való ránevelésének a legjobb eszköze az egyének mozgásának körülményeit minél inkább meghatározó tér- és időbeli elrendeződések bevezetése volt. Alakítsd úgy az üzemet, az iskolát, a kórtermet, sőt, a politikai intézményrendszert, hogy az egyén ne nagyon tudjon másként cselekedni, mint ahogyan az az adott funkció teljesítése szempontjából a legjobb. ${ }^{9}$ Azt követően azonban, hogy a tömeg megnevelődött, a versenyelőnyöket és a szervezetmúködtetés hatékonyságát már kevésbé ilyen módszerekkel, mint inkább az egyéni kulturális értékeknek és a kollektív cselekvés létrehozta többletnek a kiaknázásával lehetett biztosítani.

Meg kellett tehát ismerni az egyént, és rá kellett venni arra, hogy kibontakoztassa az adott szféra számára kincset érő tulajdonságait. A fordulat felértékelte azt, amit az egyén személyes kulturális hátterének nevezhetünk. Csakhogy ez a kulturális háttér nagyon is változatos, és értelemszerúen még változatosabbá vált egy sor közben végbement folyamat hatására. Olyanokra érdemes gondolni, amelyeket nem olyan régen még globalizációnak neveztünk. A gazdasági szervezetek túlterjeszkedtek a nemzethatárokon, de még a kontinenseken is. Ez persze már a XIX. században is zajlott, de most a dolgozókkal kapcsolatos követelmények más típusúak, jobban figyelembe kell, hogy vegyék a helyi kulturális sajátosságokat. A politikai folyamatok is átnyúltak 8 Lásd ehhez Boda Zsolt munkáit, például: Boda 2013. 
a nemzethatárokon, különösen Európában az európai integrációs folyamat következtében. A népmozgások is mind sűrübben hágták át a nemzeti és kulturális határokat, stb.

A gazdasági, társadalmi és politikai kezdeményezések és folyamatok új identitásokat teremtettek: megteremtették a nőt, a meleget, az alternatívot stb. Ezek pedig nemcsak a kreativitás forrásaiként jöttek számításba, hanem tisztelni való sajátosságokkal és mindinkább jogokkal is rendelkező kisebbségekként is. Olyan tényezők, amelyek a francia forradalom és a felvilágosodás hatására egyre inkább a magánélethez tartoztak, mint például az, hogy ki férfi és ki nő, kinek mi a vallása, ki milyen származású stb., most nyilvános harcok tárgyává lettek, politizálódtak. Ezért is történt, hogy a liberálisok a citizenship fogalmát kezdték használni, mert a különböző kisebbségek állam által nyújtott kisebbségi jogok hordozóivá is váltak. Az tehát immár a helyzet, hogy a magát valamely kisebbséghez soroló állampolgár nem akkor érzi magát a nagy társadalomba integráltnak, ha ugyanazok a jogai, mint a többségnek, hanem akkor, ha olyan többletjogokkal bír, amelyek kompenzálják az azonos jogok esetén a kisebbségi volta okán szükségképpen előálló hátrányos helyzetét.

A liberalizmus ${ }^{10}$ kezdetben nem tudott mit kezdeni a kisebbségi jogokkal, hiszen kiindulópontja az individuum, akinek a csoportkötődései inkább gyanúsak, mint értékesek. Annak idején, vagyis a polgárosodás kezdetén éppen abban fogalmazódott meg a szabadság ígérete, hogy az egyén szabaddá válhat a születése okán kényszerként ránehezedő vallási, faji, nemi, sőt, gazdasági közösségektől és besorolásoktól. Most ezzel szemben olyan helyzet állt elő, amelyben egyre többen kezdték fontosnak tartani a közösségi kötődéseiket, vagy eleve eszükbe sem jutott leválni róluk. Ráadásul ezek a felértékelődő kötődések és közösségek egyre ritkábban estek egybe a nemzettel. Amikor tehát valakinek az integráltságára gondolunk, már messze nem csak a nemzeti hovatartozása számít.

Ennek pedig legalább két teoretikus következménye van:

1. Az egyik az, hogy egyre kevésbé azonosíthatjuk a nemzetet és a társadalmat. Ha a XIX. század végén a fajt és a nemzetet szinonimaként használták a szociológusok (lásd akár Durkheim, akár Le Bon szóhasználatát), akkor most már a társadalom sem okvetlenül azonos a nemzettel és/vagy a nemzetállammal. Ebben az értelemben is alaposan végig kell gondolnunk, minek az integrációs és dezintegrációs mechanizmusait és folyamatait kutatjuk a társadalmi integráció címszava alatt.

2. A társadalmi integráció mintája sokáig, talán mindmáig az országos szintű integráció. Ez alapján képzelik el mind a kutatók, mind a döntéshozók azt, hogy mikor tekinthetünk egy társadalmat és közösséget integráltnak, hogyan kell az integráció folyamatát elősegíteni stb. A multikulturális projekt válsága valószínúleg annak is köszönhető, hogy túlságosan a nemzeti integráció, tehát valójában az asszimiláció mintájára képzeltük és képzeljük el a társadalmi integrációt.

Az említett Kymlicka megpróbál liberális alapon szembenézni ezzel, és arra jut, hogy a liberalizmussal igenis összeegyeztethető a partikuláris, a csoport kötődések felértékelődése, de csak akkor, ha a csoportok teljesítenek két feltételt:

10 Azért érdemes csak a liberalizmussal foglalkozni ehelyütt, mert a többi irányzat sokkal elfogadóbb a közösségek politikában játszott szerepét illetően. 
1. Egyik sem akar a másik csoport fölébe kerekedni.

2. A csoport nem nyomja el a saját tagjait.

Azért fontos ezeknek a számba vétele, mert immár liberális alapon is van értelme kisebbségi jogokról, a kisebbségi csoportokhoz való önkéntes és nem kényszerú (rasszista, szexista, aggista [ageist] stb. alapú) tartozásról beszélni. Amikor tehát rákérdezünk valaki integráltságára, akkor a csoportkötődését mind a kényszerek, mind pedig az önkéntes vállalások oldaláról érdemes megvizsgálni.

Alapvető könyvében Kymlicka némileg rezignáltan azzal zárja fejtegetéseit (Kymlicka 1995: 192), hogy az integráltság legfontosabb feltétele alighanem valamilyen sajátos érzelemnek a megléte az emberekben. Úgy tûnik, nemigen reménykedhetünk abban, hogy valakik olyan intézményeket fognak kitalálni és bevezetni, amelyek biztosítani tudják az adott politikai közösséghez tartozás érzését, vagyis arra késztetik az egyént, hogy fontosabbnak tartsa az állam által megfejelt politikai közösséghez tartozását, mint a vallási, etnikai, nemi, stb. identitásait, amelyek esetenként szintén politikai jellegúek.

Az integráltság fokmérőjeként még Kymlickánál is feltúnik (1995: 191) az egyéni áldozathozatal kérdése. Ekképpen ő is csatlakozik azokhoz a gondolkodókhoz, például az antik görögökhöz vagy Weberhez (1978: 903) és megint csak Durkheimhez (1982: 297), akik szerint a közösségek, a társadalmak rendszerint az élet feláldozását is elvárják a politikai közösség tagjától, mint az odatartozás bizonyítékát. Emiatt meg lehetne kockáztatni ilyen irányú kérdéseket, amelyek tehát azt firtatnák, mely közösségek és csoportok azok, amelyekért az állampolgár feláldozná anyagi javait vagy esetleg egyenesen az életét is.

\section{POLITIKAI INTEGRÁCIÓS INTÉZMÉNYEK}

A politikatudomány számos integrációs intézményt és mechanizmust tart számon. A továbbiakban a következőkről lesz szó: nemzetállam, a közjó független intézményei, pártok, tömegkommunikáció.

\section{A nemzetállam}

Mindmáig a társadalmi integráció legfontosabb intézménye alighanem az állam, jóllehet van olyan szempont, mely bizonyára a családot helyezné az első helyre. Már említettem az állampolgárság kisebbségi aspektusait, a témakör azonban ennél jóval gazdagabb. Mindenekelőtt formálisan talán a legvilágosabb jogosultságokkal az állampolgárság jár, tehát ez integrálja az állam által reprezentált politikai közösségbe az egyént. A különböző felfogások másként és másként tekintenek az állam által biztosított jogokra. Az egyik értelmezés szerint az egyén állampolgárként eleve hordozója egy sor jognak, míg más megközelítésben a jogokhoz közvetlenül felelősség is társul, megint máshonnét közelítve: a jogok megléte csak akkor bizonyos, ha folyamatosan készen állunk megvédeni őket akár az állammal szemben is. Ezekre a variációkra érdemes rákérdezni az empirikus kutatások során.

Különösen aktuális kérdés Magyarországon az állampolgárságnak a határon túli magyarokra való kiterjesztése. Vajon milyen hatással jár ez azoknak az integrációs érzületére, akik ezt frissen kapták, és hogyan azokéra, akik végigkísérték a folyamatot és ezzel egyben a választó jog kiterjesztését is. Ebben az egyik fokmérő 
az új választópolgárok 2014-es választási részvétele és annak hazai és helyi közéleti lecsapódása. Ebből levonhatunk következtetéseket arra nézve, hogy az állampolgárság mennyiben integrálja az országtól távol élóket a magyar politikai közösségbe.

Az állam az állampolgárságon túl számtalan eszközt múködtet az emberek integrálása végett. Olyanokra érdemes gondolni, mint a kultúra terjesztése a kötelező oktatás (nyelv, történelem, irodalom, nemzeti múvészeti alkotások stb.), a kultúratámogatás (múzeumok, színházak, közszolgálati músorszolgáltatók, nemzeti filmgyártás fenntartása és támogatása stb.) és más eszközök révén. Külön figyelmet érdemel, mivel célzott oktatásról van szó, az iskolai állampolgári nevelés kérdése.

Ezeknek az integrációs tevékenységére és teljesítményére érdemes rákérdezni, de valószínúleg annyira magától értetődően vannak jelen az emberek életében és múltjában, hogy nem tudnak kívülről rájuk tekinteni, vagy velük szemben viszonyt kialakítani. ${ }^{11}$ Ugyanakkor azt meg lehet kérdezni, hogy vajon az állampolgár úgy érzi-e, hogy a színházon, magyar filmen vagy a televízió músorokon keresztül számításba veszik őt is olyanként, aki a nemzeti közösséghez tartozik és ezért kiszolgálandó, kap-e olyan ismereteket, értékeket és benyomásokat, amelyek eligazítják a nemzet, a társadalom múltját, jelenét és jövőjét illetően, amelyek összekötik a közösség múltbeli, jelenbeli és jövendő tagjaival.

Megvizsgálandó, de ez a mai magyar politikai helyzetben jelentős átfedésben van a pártok kérdéskörével, a nemzeti összetartozás események általi létrehozatala és megerősítése. Az előbbiekben említett integratív eszközök intézmények, amelyeket vagy igénybe vesz valaki, vagy nem. Nem érdektelenek azonban azok a politikai események, amelyek alkalomszerúek, ezért kevéssé intézményesítettek, jóllehet rendszeres időközönként megrendezik őket. Az állami ünnepekre és rendezvényekre gondolunk, ahol állam alatt most a helyi önkormányzatot is értjük. Ezeknek a nyíltan bevallott célja az adott helyi vagy országos közösség együvé tartozásának a megjelenítése, amikor ráadásul az összetartozás nemcsak a jelenben élőkre, hanem a múltbeliekre is vonatkozik. Az elméleti irodalom szerint (Berezin 1997) a politikai elit rendszeresen kezdeményez ilyen rendezvényeket, mégpedig a nemzeti és közösségi érzület megerősitése végett, de az nehezen számítható ki előre, hogy az adott esemény eléri-e a célját. Ezt úttörő dolog lenne empirikusan vizsgálni - valószínúleg nemzetközileg is újdonság lenne erre vonatkozó eredményekkel előállni. ${ }^{12}$

\section{A közjó intézményei}

Pierre Rosanvallon Lefort tanítványa, aki szinte egy az egyben folytatja annak gondolatmenetét, sőt, társadalom- és politikatörténeti elemzéseivel világosabbá teszi Lefort felettébb filozofikus fejtegetéseit. Rosanvallon szinte minden munkája a hatalom és az üres hely, a fellelhetetlen nép (Rosanvallon 1998) problémájából indul ki. Ő is a király lefejezésével kezd, és az ebből kiinduló történelmi ív felvázolásával folytatja. Különös érdekességgel bír számunkra az, ahogyan az általa előadottak segítségével megvilágosodik, miért is válik annyira fontossá egészen a közelmúltig az az arisztotelészi hagyomány, mely mindenekelőtt az intézményeket tekintette az egészséges politika biztosítékának, s ezért kiváltképp azok vizsgálatára összpontosított.

11 Lásd ehhez Billig (1995) fogalmát a hétköznapi nacionalizmus megragadására.

12 Első próbálkozásokként lásd: Kiss-Szabó-Antal 2014, Kiss 2015. 
Rosanvallon (2008) szerint a XIX. század végére Európa-szerte végbement a kiábrándulás a népszuverenitás elvéből, mert nagyon is láthatóvá vált, hogy a parlamentek nem arra szolgálnak, hogy az ottani viták révén kialakuljon a közjó és az általános érdek, ami megjelenítette volna a nép egységét. A pártok és politikusok vitái, vagy veszekedései inkább a partikuláris érdekek torzsalkodásai és alkudozásai voltak. Ebből a kiábrándulásból két alternatíva alakult ki az 1890-től 1920-ig tartó időszakban.

A totalitárius megoldás félretolta a veszekedő és korrupt pártokat, hogy az egyetlen Párt akadálytalanul összeolvadhasson a társadalommal. A totalitárius pártok azt hirdették, hogy integrálják az alsóbb néposztályokat a nép, tehát a politikailag releváns népesség egészébe, a társadalom testébe, és számos lépést tettek is ebben az irányban.

A másik a nyugati opció volt. Ennek a jegyében fennmaradt ugyan a választásos, többpártrendszeres parlamenti berendezkedés, de mivel ettól nem remélték a közjó és az általános érdek megfogalmazását és megvalósítását, ezért úgynevezett független intézményeket kezdtek létrehozni. Ezeket ismerjük máig is: a nemzeti bankok, az alkotmánybíróságok tartoznak ide, Franciaországban és másutt is a közoktatás egész rendszere, de - bár Rosanvallon nem említi őket - ide sorolhatjuk a független sajtót és a pártatlan tudományt is. Természetesen az egyes országokban más és más területeken jöttek létre független intézmények, van, ahol például nincs is alkotmánybíráskodás, vagy ahol a sajtó nem lett független. ${ }^{13}$

Az intézmények függetlensége elsősorban a pártokkal szemben fogalmazódott meg, hiszen csak így lehettek képesek arra, hogy meghatározzák és megvalósítsák a közjót, az általános érdeket. Az intézmények sok ideológiai munkát öltek abba, hogy erős független identitást alakítsanak ki és tartsanak fenn, de számos kiválasztási és értékelési eljárás is ezt volt hivatott szolgálni. Míg a XIX. században szerte a demokráciákban az volt a természetes a magángazdaságban is, de még inkább a közszférában, hogy az állásokat politikai beállítottság, illetve párttagság alapján kapja valaki, s magától értetődő volt, hogy választásokkor teljes váltás ment végbe a posztokon, ${ }^{14}$ addig most már az sem volt elfogadható, ha az állami tisztviselóket lecserélte az övéire az új kormánypárt.

Nem meglepő, hogy Max Weber ekkor fogalmazza meg a szakszerű bürokrácia elveit, s hogy a profeszszionalizmus és a tudományos alapú vezetés válik értékké. Rosanvallon nem foglalkozik ezzel, de tudjuk, hogy az elfogulatlan, objektív tudomány eszméje, s az ugyanezeken az értékeken nyugvó tudósidentitás is ekkor válik tömegessé. A korszak különösen felértékeli a társadalomtudományokat, hiszen a logika szerint a szakszerű társadalomirányításhoz elfogulatlan társadalmi ismeretekre van szükség. A (társadalom)tudomány képes arra, hogy pártatlanul jusson el az egyedül racionális ismeretekhez, szemben a pártok politikai tudásával.

A folyamat megállt vagy lelassult a hetvenes években. A thatcheri és reagani időktől kezdve felerősödött a kritika a független intézményekkel szemben. Pazarlással és felelőtlenséggel vádolják őket, mégpedig azon az alapon, hogy mivel nincsenek alárendelve sem a piacnak, sem a pártoknak, ezért sem közvetlen, sem közvetett legitimációval nem rendelkeznek. A New Public Management jelszava alatt új filozófia született a közintézmé-

13 Lásd ehhez Hallin és Mancini Médiarendszerek (2008) címú könyvét, mely nem tekinti történelmi tendenciának azt, hogy a demokráciákban angolszász típusú kiegyensúlyozott média alakuljon ki.

14 Max Weber is felfigyel a spoils systemre a Politika mint hivatásban: Weber 1995: 101-103. 
nyek múködtetését illetően (Hajnal 2004). Normává vált a piaci logika, a marketing, a public relations alkalmazása, az, hogy az állampolgárokat a klienseiknek, sőt, a vásárlóiknak tekintsék.

Rosanvallon alapján világos, hogy a polgárok integráltsága, tartozása valahová, amit jobb híján társadalomnak vagy politikai közösségnek nevezünk, korántsem kézenfekvő a demokrácia körülményei közepette. Aligha lehetséges beérnünk Weber definíciójával, mely szerint azok alkotják a politikai közösséget, akik hajlandók erőszakkal is megvédeni egy földrajzilag körülírt területet. ${ }^{15}$

\section{Pártok}

Ahogyan említettem, a pártok integrációs képességei hosszú ideig felettébb kérdésesnek mutatkoztak. A görög kezdetek óta egészen a XIX. századig a politikai gondolkodók és a gyakorló politikusok túlnyomó része gyanakvással tekintett a pártokra, mert inkább az egyet nem értés és széthúzás eszközeinek, mint az integráció előmozdítóinak látták őket (Sartori 2005). Ha az érdekcsoportok pártokká szerveződnek, akkor a gazdasági vagy más szembenállásukat a politikában is érvényesíteni fogják. A XX. századra azután végképp elfogadottá váltak a pártok, mégpedig azon az alapon, illetve abban a reményben, hogy a társadalmakra érdek és érték pluralitás jellemző ugyan, s jogállamban ezek elnyomása nem is lehetséges, tehát a társadalom nemcsak plurális, hanem pluralista is, ám ezek az érdek és érték ellentétek keresztbevágják egymást. Egy állampolgár gazdasági alapon tartozhat ugyan egy adott csoporthoz, de a vallása vagy az etnikai kötődései okán más csoporthoz vagy csoportokhoz tartozik, ezért az egyes kötődései nem halmozódnak veszélyesen egymásra.

Innentől kezdve lehetővé vált az, hogy a pártokra immár éppen ellenkezőleg gondoltak, mégpedig úgy, mint az állampolgárokat politikailag integráló szervezetekre. A pártok (kellene, hogy) benne élve a társadalomban a felszínre hozzák a társadalmi feszültségeket, hangot adnak az állampolgári törekvéseknek, kompromiszszumok révén feloldják az érdekütközéseket, tájékoztatják a polgárokat a nemzet fontos ügyeiről, kinevelik a kormányzati politikusok újabb és újabb generációit stb. Egyszóval: a legfontosabb csatornát képezik az állampolgár és a politikai döntéshozatal között.

Sokáig az állampolgárok be is léptek a pártokba, különösen a XX. század folyamán, amikor tömegpártok léptek a korábbi elitpártok helyébe. A politika és ezen belül például a politikai kommunikáció és a kampányok professzionalizálódása azonban leértékelte a párttagságot a pártvezetés szemében, de az állampolgárok szemében is (Norris 2001). A pártok nem csak a kampányolásban szorultak inkább a televízióra, majd az internetre, mint a tagságra, hanem a finanszírozásuk tekintetében is, mert mind több országban az állam támogatja a múködésüket.

A pártok összementek, ahogyan a tagság kiöregedett, mert a fiatalok nem léptek be. Ennek meglett az a következménye, hogy az egyre idősebb tagság választotta meg a pártvezetőket, akik aztán kormányzati vezetőkké is váltak, s az idős tagság döntött a pártprogramról is, amelyik adott esetben kormányprogrammá is válhatott (Goerres 2009). Fennállt tehát annak a veszélye, hogy a pártok nem képesek ellátni a politikai integrációban rájuk rótt feladatokat, mert egyre kevesebbek érdekeit és értékeit képviselik. 
Valójában a helyzet messze nem ilyen borús. Egy friss kutatás szerint (Hooghe-Kern 2013) a párttagság csökken ugyan, de a pártokkal való azonosulás nem. Úgy túnik, a pártok megtalálták azokat a módszereket, amelyek segítségével tagfelvétel nélkül is képesek nagy tömegeket integrálni a politikába és ezen keresztül a politikai közösségbe. Ezek az alternatív utak részben a következőkben röviden tárgyalt mozgalmakon keresztül vezetnek.

Akárhogy is, a pártokat továbbra is figyelembe kell vennünk akkor, amikor rákérdezünk a társadalmi integráció mértékére. Amit el kell kerülni, az a pártokhoz fúződő viszony leegyszerüsítése a párttagságra és a párttagsághoz füződő viszonyra, vagy akár a pártválasztásra. Különösen bizonyos pártok esetében a mozgalmi holdudvar, de nem utolsó sorban a párthoz lazán kötődő média, a kulturális miliő, a szubkultúra az, amelyen keresztül a pártok szimpatizánsi tábort toboroznak maguk köré. De integratív lehet a pártvezér személye is.

A politikai integráció tehát sokszor egyáltalán nem a hagyományos értelemben politikai platformokon és csatornákon keresztül megy végbe. Általában is számolnunk kell a politika és a nem politikai világ közötti határvonal elmosódásával, ami különösen megnehezíti a kutatást azt a korszakot követően, amikor az intézményközpontúság okán még élesek voltak a kontúrok.

\section{Tömegmédia}

Említettem már a tömegmédiát mint az állam és a pártok kommunikációs és indoktrinációs csatornáját. A tömegkommunikáció azonban egyáltalán nem kizárólag jól vagy rosszul múködő csatorna, amelyen át a politikai intézmények és szervezetek eljuttathatják az üzeneteiket az állampolgárokhoz, hanem maga is politikai szereplő önálló politikai és ezzel párhuzamosan társadalmi integrációs szereppel. A tömegkommunikációs szereplőknek nagyon sokszor van saját véleményük, sőt, saját stratégiájuk a társadalom és a politika fejlődését és fejlesztését illetően.

A tömegmédia ismeretekkel látja el az állampolgárokat, de sokszor az intézményeket is. Értékeket is közvetít az ismeretátadás közben és attól függetlenül is. Érzelmeket is kelt, valamint teret enged azoknak a beszélgetéseknek, amelyek - mint Lefort-nál olvastuk - a legfontosabb társadalomintegráló tevékenységek a láthatatlan ideológia korszakában.

Mindig is úgy tartották a gondolkodók, hogy a kommunikációs médiumok kulcsszerepet játszanak a közösség, a politikai közösség összetartásában, az egyén közösségi hovatartozásának létrehozatalában és fenntartásában. Minden újabb és újabb médiumban, tehát az újságban éppen úgy, mint a könyvben, a filmben, a rádióban, a televízióban, valamint újabban az internetben és a szociális hálóban (social media) az atomizált, egymástól elszigetelt emberek egymásra találásának, egymás és a nagy közösség iránti elkötelezettségének az eszközét látták, még akkor is, ha számosan félelmeket is tápláltak ugyanezek miatt a médiumok miatt.

Az újabban nagyobb ismertségre szert tett Benedict Anderson (2006) a médiumokra, éspedig a könyvekre éppúgy, mint az újságokra mint kulturális tényekre hivatkozva beszél az elképzelt közösségekről. A nacionalizmus, a nemzethez tartozás alapja szerinte az, hogy az emberek elkezdik magukat egy olyan embertömeg részének tekinteni, amelynek a túlnyomó részét soha nem fogják személyesen még látni sem, nem hogy megismerni. Ennek a valójában soha meg nem ismerhető sokaságnak az elképzeléséhez, mégpedig mint ismert és 
hozzájuk hasonlóan élő emberek halmazának az elképzeléséhez a könyvek és általában a tömegkommunikáció ad anyagot és segítséget.

A gondolat tulajdonképpen Tarde-nál is szerepel már. Ő különbözteti meg először egymástól a fizikailag együttlevő tömeget és a szétszórt sokaságot. Az előbbit tömegnek (foule), az utóbbit köznek (public) nevezi el, és így teszi lehetővé azt, hogy az emberek összessége a szétszórtság ellenére tudományosan és hétköznapian is összetartozó közösségként legyen elképzelhető és vizsgálható. A szó a közvélemény (public opinion) szóban és a nyilvánosság (public sphere) megnevezésében is megjelenik.

Kutatásaink során rákérdezhetünk ennek az elképzelt közösségnek a meglétére. Egészen pontosan arra, hogy az állampolgárok mely emberekből állónak tekintik a maguk elképzelt közösségeit.

\section{AZ INTEGRÁCIÓ AKTÍV FORMÁl}

A továbbiakban olyan formákat veszek szemügyre, amelyeket az állampolgárok valóban igénybe vesznek. Ezek közé tartoznak az elkötelezettség formái és a különféle részvételi formák, köztük a mozgalmak és szerveződések, valamint a szociális háló.

\section{Elkötelezettség}

Az integráltság egyik lehetséges állapota és aspektusa a társadalmi ügyekre való állampolgári odafigyelés - ezt a brit szóhasználat engagementnek nevezi (Dahlgren 2009). Aligha kérdéses, hogy amennyiben az emberek odafigyelnek a politikai és egyéb társadalmi történésekre, akkor az adott közösség részének tekinthetjük őket, mégpedig akkor is, ha fizikailag nem tartózkodnak az ország vagy az adott földrajzilag körülírható közösség területén.

Az elkötelezettségnek számos formája lehet az újságolvasástól, híradónézéstől, online hírportálok látogatásától a nyilvános politikai és társadalmi vitákon való részvételig, vagy éppen a közélet kérdéseinek a baráti körben történő megvitatásáig. Ennek a kikutatása is lehetséges akár survey, akár kvalitatív módszerek segítségével.

\section{Participáció}

Az engagementnél erősebb a participációnak, a jelen esetben a politikai részvételnek a fontossága a társadalmi integráció mérése és nyomon követése számára. A politikai részvételnek számos formája különböztethető meg; az egyik leghagyományosabb formát, a választási részvételt már említettem. Ez a politikai rendszer által felkínált lehetőség, amellyel kapcsolatban az lehet a kutatási kérdésünk, hogy vajon igénybe is veszik-e az állampolgárok.

Hasonlóképpen a felkínáltak közé tartozik a pártok által indított aláirásgyűjtés, tüntetési felhívás, közös rendezvényre szóló meghívó, adakozási kérelem stb. Minden ilyen esetben a kínálat aktív elfogadása bízvást tekinthető az integráltság bizonyítékának. Két szempontot érdemes itt még figyelembe venni:

1. Mivel pártok kezdeményezéseiről van szó, ezért külön vizsgálandó, hogy az integráció vajon csak az 
adott pártra, az adott párt által reprezentált politikai közösségre vonatkozik, vagy a párton keresztül valóban az egész politikai közösségre is, amelynek az adott párt lojális része.

2. Egy sor részvételi forma efemer, rövid életü. A társadalmi integrációnak tehát részei olyan cselekvések is, amelyek időhorizontja nagyon változatos lehet. Nem célszerú kizárólag a tartós, évtizedes formákat tekinteni az integráció bizonyítékának, mert az állampolgárok különböznek ilyen irányú preferenciáik tekintetében.

\section{Mozgalom}

Az egyik legfontosabb forma manapság a mozgalmi részvétel. Valaha a mozgalmak gyanúsak voltak a politikatudomány szemében, mert a funkcionalista megközelítés számára a pártok és más felkent politikai intézmények voltak azok, amelyeken keresztül az állampolgárnak a politikai szándékait érvényesítenie kellett volna (Koopmans 2007). A hetvenes évektől kezdve azonban a hatvanas évek diáklázadásainak résztvevői váltak a politikatudomány derékhadává, s már csak ezért is a diszciplína sokkal barátságosabban tekintett a mozgalmakra. Eljutottunk ahhoz az állásponthoz, hogy nem számít egészségesnek az a politikai berendezkedés, ahol nincsen kellő számú civil politikai mozgalom.

A mozgalmak szerencsés esetben valóban megvalósítják a politikai integráció feladatát, mégpedig a pártoknál rugalmasabb módon. A pártok ugyanis tartós szervezetek, míg a mozgalmak akár átmenetiek is lehetnek, melyek csak addig léteznek, ameddig egy-egy ügy, amelyre szerveződtek, dúlőre nem jut. A mozgalmon belül lehetnek ugyan szervezetek is, de a csatlakozó állampolgárok viszonya sokkal esetlegesebb, mint a párttagoké.

Ez a rugalmas és efemer jelleg mintha még inkább megerősödött volna az utóbbi egy-két évtizedben - nem utolsó sorban az internet, majd a Web 2.0 létrejöttének és elterjedésének a következtében. Egyre sűrủbben fordulnak elő szervezettel már gyakorlatilag egyáltalán nem rendelkező megmozdulások - ezeket hívja Bruce Bimber (Bimber-Flanagin-Stohl 2012) organization-less organizingnak, vagyis szervezet nélküli szerveződésnek. Olyan jelenségekre kell gondolni, mint Magyarországon az Alföldi Róbert melletti vagy az Új Színház új vezetése elleni tiltakozások, de mindig is megjelent számos rövidebb-hosszabb életű megmozdulás a magyar politikai színpadon 1990 óta.

Külön említést érdemelnek olyan formák, mint a vásárlással megvalósuló bojkott, vagyis, hogy az állampolgár nem vásárol bizonyos termékeket, mert így kíván tiltakozni a termelő vagy a fogyasztó eljárásai ellen. A forma a XIX. század végéig nyúlik vissza, de mióta a fogyasztói identitás felértékelődött, azóta mind több ilyen kezdeményezésnek engednek az állampolgárok (Cohen 2001).

Az ilyenekben való részvétel mérendő a kutatás során.

\section{Online részvétel}

Az internettől sokan és sokáig várták a politikai és társadalmi integráció megélénkülését és megerősödését. Az internet a maga huszonnégy órás nyitva tartásával minden állampolgár személyes élethelyzetéhez igazodva szolgálja a társadalom ügyeiről való tájékozódás és a szervezetekhez vagy a más állampolgárokhoz való fordulás igényét. Az anonimitás okán még csak attól sem kellett senkinek tartania, hogy a politikai vagy 
bármilyen kiállása visszaüt rá. A Facebook és más Web 2.0-ás lehetőségek szúkítették ugyan az anonimitás terét, de addigra ez már kevéssé tûnt zavarónak a magyar állampolgárok számára, egyre nyíltabban fejezik ki, performálják politikai és egyéb identitásukat.

Az online részvétel formái nagyon gazdagok és folyamatosan bővülnek, egyéni befektetésigényük egészen szélsőségesen változik az észrevétlen olvasástól a lájkoláson át a szofisztikált online jelenlétig. A leggyakoribbnak a Facebookon, Twitteren, Youtube-on és hasonló felületeken való aktív részvétel számít, mely kétségkívül integrálja az állampolgárt valamely közösségbe, jóllehet ezeknek a közösségeknek a terjedelme és tartalmi vonatkozásai szerfelett változatosak. A social media mellett a blogolás és kommentelés már-már helyettesíteni látszik sokak számára az újságírás és hírfogyasztás hagyományos, professzionális formáit.

A kutatás során mindenképpen szükséges erre a területre hangsúlyosan rákérdezni, ugyanis főként a fiatalabb korosztály, de mások számára is, fontosak ezek az integrációs formák.

\section{ÖSSZEFOgLALÓ}

A tanulmány ötletek egyfajta összefoglalójaként megkísérelte bemutatni azt, milyen szélesen lehet és érdemes a társadalmi integráció kérdéskörét megközelíteni manapság. Elsősorban a politikai integráció aktív és passzív formáira összpontosítottam, mivel azonban a politika és a politikán kívüli társadalmi szférák, intézmények és cselekvések elkülönítése viszonylagos, ezért szó került az általában vett társadalmi integráció néhány mechanizmusára is.

Mindezek nyomán hét dimenzió mentén vizsgálhatjuk a (politikai) integrációt: közösségtípus, cselekvési dimenzió, ideológiai dimenzió, objektivitás és percepció, mentális, földrajzi, időbeli összetartozás.

Közösségtípus. Ez a dimenzió azzal vet számot, hogy többféle közösség is integrálhatja az embereket. Maga a politikai közösség is legalább két szinten értendő: az országos/nemzeti szinten, és az egyes politikai táborok szintjén. Beszélhetünk azután különféle társadalmi integrációs közösségekről, olyanokról, mint az önsegítő csoportok, az önkéntes társulások, a vallási vagy etnikai közösségek. Megint más típusú közösségek a családok, a baráti társaság, a munkahely vagy az online kommunikációs közösség, mely szintén kínál integrációs csatornákat és interakciókat.

Cselekvés. Ez a dimenzió az integrálódás mikéntjét, eszközét írhatja le, azt tehát, ahogyan, aminek a révén az emberek integrálódnak, vagy integrálódhatnának. A politikai integráció tekintetében a leghagyományosabb és legformálisabb az állampolgárság. Ennél aktívabb a választási részvétel, a pártba való belépés, a pártrendezvényeken való jelenlét, a vezérekkel való azonosulás. Idesorolhatjuk a jóléti szolgáltatások igénybevétele általi integrálódást vagy a politikai intézmények kulturális természetű integrációs erőfeszítéseit. A mozgalmakban való aktiv részvétel is integrál, amiképpen a szervezet nélküli szerveződések is ideig-óráig. Választhat az egyén olyan eszközöket is, mint a tüntetés, a petíciók kezdeményezése és aláirása, az online részvétel vagy bizonyos termékek politikai vagy morális alapon történő megvásárlása vagy bojkottálása. Végül az egyéni integratív cselekvés legalsó foka a puszta érdeklődés a (politikai) közösségek ügyei iránt. 
Ideológiai dimenzió. Ez a dimenzió az, amelyik megjeleníti, elképzelhetővé teszi a társadalmi integrációt. Ebbe a körbe tartoznak az ideológiai intézmények által felkínált diskurzusok és hívószavak, metaforák a Nemzetről, Európáról, a Magyarságról, a Kereszténységről, a Modernségről és Szabadságról stb. Lefort nyomán vizsgálhatjuk a „láthatatlan ideológiát” is, mely tehát azon alapszik, hogy mindenkiről állítható, hogy valamilyen közösséghez tartozik, és hogy részt vehet a társadalmi kommunikációban.

Objektivitás és percepció. Ez a dimenzió a szerint tagozódik, ami egyfelől tudományosan felmutatható, másfelől pedig ami az egyén számára valósan, szubjektíve is jelen van. Például objektíve vizsgálva a különféle intézmények kínálnak integrációs formákat és csatornákat. Az iskolák nemzeti érzelmeket és egymás megértésének kulturális kapaszkodóit, a munkahelyek egzisztenciális integrálódást, de akár kollektívát is, s az egyén az által is érezheti otthon magát a világban, hogy talál-e az üzletekben vagy a médiában kifejezetten neki szánt fogyasztanivalót stb. Kérdés azonban, hogy az egyén az integrálására szánt csatornákat és eszközöket, ideologémákat és termékeket a magáénak érzi-e.

Mentális. A mentális dimenzió az integrálódás és integráltság kognitív, attitüdinális és érzelmi összetevőit vizsgálhatná. Milyen tudatos ismeretei vannak a magyar polgárnak a társadalmi integrációról általában, az egyén integráltságáról azon belül? Mely közösségekhez tartozás képezi az identitásának a részét? Milyen érzelmek fúzik az egyes integrációs ágensekhez?

Földrajzi. Az integrációs közösségek különböznek egymástól a térbeli elhelyezkedésüket tekintve. Van értelme lokális, tehát lakóhelyi odatartozásról, regionálisról, nemzetiről és európai azonosulásról, identitásról is beszélni. De nem értelmetlen megvizsgálni a globális összetartozás jelenlétét, értékét, inspiratív jellegét sem.

Időbeli. Az integráltság és az integrálódási igény idődimenzióval is bír. Például a közvélemény-kutatási adatok rendre azt mérik, hogy a politikai azonosulás a választások közötti években jóval alacsonyabb, mint a választási részvétel. Itt tehát hullámzás tapasztalható, nem pedig egyszer s mindenkorra adott azonosulási szint. Hasonlóképpen az összetartozás időbelisége alá sorolhatjuk az emlékezet általi azonosulást a legkülönfélébb múltbeli közösségekkel a rokonságtól a történelmi hősökig, sikerekig és szégyenfoltokig. Végül az integráció irányulhat a jövő felé is: például felelősséget érezhetünk és kelthetnek bennünk a jövendő nemzedékek, az ország, a nemzet, Európa és az emberiség jövője iránt. 


\section{HIVATKOZÁSOK}

Anderson, B. (2006) Elképzelt közösségek. Gondolatok a nacionalizmus eredetéröl és elterjedéséröl. Budapest: L'Harmattan.

Berezin, M. (1997) Making the Fascist Self. The Political Culture of Interwar Italy. Ithaca, NY: Cornell University Press.

Billig, M. (1995) Banal Nationalism. London: Sage. http://dx.doi.org/10.4135/9781446221648.

Bimber, B. - Flanagin, A. - Stohl, C. (2012) Collective action in organizations: interaction and engagement in an era of technological change. Cambridge- New York: Cambridge University Press. http://dx.doi.org/10.1017/CBO9780511978777.

Boda Zs. (2013) Legitimitás, bizalom, együttmüködés. Kollektiv cselekvés a politikában. Budapest: Argumentum - MTA TK PTI.

Candea, M. (ed.) (2010) The Social after Gabriel Tarde: Debates and Assessments. New York: Routledge. http://dx.doi.org/10.4324/9780203876312.

Clark, T. N. (1969) Introduction. In Tarde, G. On Communication and Social Influence. Chicago: The University of Chicago Press.

Cohen, L. (2001) Citizen consumers in the United States in the century of mass consumption. In Daunton, M. - Hilton, M. (eds.) The Politics of Consumption. Oxford: Berg, 203-222.

Collins, R. (1994) Four Sociological Traditions. Oxford: Oxford University Press.

Collins, R. (2004) Interaction Ritual Chains. Princeton: Princeton University Press. http://dx.doi.org/10.1515/9781400851744.

Dahlgren, P. (2009) Media and political engagement: Citizens, communication, and democracy. Cambridge: Cambridge University Press.

Durkheim, É. (1890-1900) Leçons de sociologie. http://dx.doi.org/10.1522/cla.due.lec.

Durkheim, É. (1982) Az öngyilkosság. Budapest: Közgazdasági és Jogi Könyvkiadó.

Durkheim, É. (2001) A társadalmi munkamegosztásról. Budapest: Osiris.

Ferri, E. (1881/1900) Sociologia criminale. Torino: Frattelli Bocca.

Frampton, K. (1985) Critical Regionalism: modern architecture and cultural identity. In Modern Architecture: A Critical History. London: Thames and Hudson, 313-327.

Freud, S. (1921/1995) Tömegpszichológia és én-analízis. In Tömegpszichológia. Társadalompszichológiai írások. Budapest: Cserépfalvi. $185-248$.

Goerres, A. (2009) The Political Participation of Older People in Europe. The Greying of Our Democracies. London: Palgrave MacMillan. http://dx.doi.org/10.1057/9780230233959.

Goffman, E. (1961) Encounters: two studies in the sociology of interaction. New York: The Bobbs-Merrill Company.

Hajnal Gy. (2004) Igazgatási kultúra és New Public Management reformok egy összehasonlító tanulmány tükrében. Budapest: BCE.

Hallin, D. C. - Paolo M. (2008) Médiarendszerek. A média- és politikai rendszerek három modellje. Budapest: Gondolat.

Hogg, M. (2001) A Social Identity Theory of Leadership. Personality and Social Psychology Review, 5, 184-200.

Huddy, L. (2001) From Social to Political Identity: A Critical Examination of Social Identity Theory. Political Psychology, 22, 1, $127-156$. http://dx.doi.org/10.1111/0162-895x.00230.

Hooghe, M. - Kern, A. (2015) Party membership and closeness and the development of trust in political institutions: An analysis of the European Social Survey, 2002-2010. Party Politics, November, 944-956. Online first.

Illouz, E. (2008) Saving the Modern Soul. Berkeley, CA: University of California Press.

Kantorowicz, E. (1957) The King's Two Bodies: A Study in Mediaeval Political Theology, Princeton University Press.

Kiss B. (2013) Érzelmek és politikatudomány. Politikatudományi Szemle, 3, 7-28.

Kiss B. (2014) Szituáció és interakció. Politikatudományi Szemle, 3, 119-124.

Kiss B. (2015) Politikai közösség kilencven perc alatt. Identitásváltások kognitív, értékelő és érzelmi dinamikája. Politikatudományi Szemle, 2, 57-89.

Kiss B. - Szabó G. - Antal A. (2014) Politikai nagygyúlések mint interakciós rituálék. 2013. október 23. a Hősök terén, a Deák téren és a Múegyetem előtt. Politikatudományi Szemle, 2, 7-29.

Koopmans, R. (2007) Social Movements. In Dalton, R. J. - Klingemann, H.-D. (szerk.) The Oxford Handbook of Political Behavior. Oxford: Oxford University Press. 693-707. http://dx.doi.org/10.1093/oxfordhb/9780199270125.001.0001.

Körösényi A. (2005) Vezér és demokrácia. Budapest: L’Harmattan. 
Kymlicka, W. (1995) Multicultural Citizenship. A Liberal Theory of Minority Rights. Oxford: Clarendon Press.

Kymlicka, W. - Norman, W. (2000) Citizenship in Culturally Diverse Societies: Issues, Contexts, Concepts. In (uők szerk.) Citizenship in Diverse Societies. Oxford: Oxford University Press, 1-43. http://dx.doi.org/10.1093/019829770x.003.0001.

Latour, B. (2002) Gabriel Tarde and the end of the social. In Joyce, P. (ed.) The Social in Question: New Bearings in History and the Social Science. London: Routledge.

Lefaivre, L. - Tzonis, A. (2003) Critical Regionalism: Architecture and Identity in a Globalised World. New York: Prestel.

Lefort, C. (1978) Les formes de l'histoire. Essais d'anthropologie politique. Párizs: Gallimard.

Lefort, C. (1981) L'Invention démocratique. Les limites de la domination totalitaire. Párizs: Fayard.

Le Bon, G. (1895/2012) A tömegek lélektana. Onga: Belső EGÉSZ-ség.

Lombroso, C. (1876) L'uomo deliquente. Milano: Hoepli.

Norris, P. (2002) Campaign Communications. In LeDuc, L. - Niemi, R. - Norris, P. (eds.) Comparing Democracies 2: Elections and Voting in Global Perspective. London: Sage, 127-147.

Riker, W. H. (1982) Liberalism against Populism. San Francisco: W. H. Freeman.

Rosanvallon, P. (1992) Le sacre du citoyen. Histoire du suffrage universel en France. Paris: Éditions Gallimard.

Rosanvallon, P. (1998) Le peuple introuvable. Histoire de la représentation démocratique en France. Paris: Éditions Gallimard.

Rosanvallon, P. (2006) Democracy past and future. New York: Columbia University Press.

Rosanvallon, P. (2008) La légitimité démocratique. Impartialité, réflexivité, proximité. Paris: Éditions du Seuil.

Sartori, G. (2005) Parties and party systems: a framework for analysis. Colchester: ECPR Press.

Scheff, Th. J. (1990) Microsociology. Discourse, Emotion, and Social Structure. The University of Chicago Press.

Sighele, S. (1895) La folla delinquente: Studio di psicologia collettiva. Fratelli Bocca.

Szabó M. (1996) Vázlat a politika diszkurzív értelmezéséről. Politikatudományi Szemle, 5, 4, 103-132.

Taine, H. (1878) Les Origines de la France contemporaine. Tome II: La Révolution: I'anarchie. Paris: Hachette. http://dx.doi.org/10.1522/24799893.

Tarde, G. (1890) La Criminalité comparée. http://dx.doi.org/10.1522/cla.sif.tag.cri.

Tarde, G. (1890) Les Lois de l'imitation. http://dx.doi.org/10.1522/cla.tag.loi1.

Tarde, G. (1901) L'opinion et la foule. http://dx.doi.org/10.1522/cla.sif.tag.opi.

Weber, M. (1978) Economy and Society. Berkeley: University of California Press.

Weber, M. (1995) A tudomány és a politika mint hivatás. Budapest: Kossuth. 